\title{
Early rehabilitation in ICU for COVID-19: what about FES-cycling?
}

\author{
Gaëlle Deley ${ }^{1 *} \mathbb{B}$, Davy Laroche ${ }^{1}$ and Jean-Pierre Quenot $^{2}$
}

Dear editor,

We read with great interest the article by Nakamura et al. [1] discussing the use of belt-type electrical muscle stimulation (EMS) for early rehabilitation in severe COVID-19. Authors suggested that among the various possibilities of EMS (i.e., application of a series of stimuli to skeletal muscle to trigger muscle contractions), belttype EMS could be effective for critical care because it can induce whole lower extremity exercise. Such exercise could be of great interest in the early acute phase in order to counteract Intensive Care Unit-Acquired Weakness (ICUAW). Indeed, although knowledge of COVID-19 per se is still incomplete, it is reasonable to assume, based on what we know from other severe respiratory syndromes, that COVID-19 patients may present ICUAW-associated consequences, such as physical, mental, and cognitive dysfunctions [2].

For these reasons, rehabilitation appears as a key component of these patients' care. More specifically, international experts highlighted that early rehabilitation (with active involvement by a physiotherapist) can drastically improve activities of daily living, exercise function, length of hospital stay, and mechanical ventilation [2] and would likely play a major role in promoting a functional return to home for the patients [3].

Although the method presented by Nakamura et al. [1] is interesting, it is essential that early rehabilitation following COVID-19 also targets cardiovascular, cognitive, functional, and mobility reconditioning [2]. Such benefits

*Correspondence: gaelle.deley@u-bourgogne.fr

1 INSERM UMR1093 - CAPS, Faculty of Sport Sciences, University of Bourgogne Franche-Comté, 21000 Dijon, France

Full list of author information is available at the end of the article require exercise intensities that might not be reachable with belt-type EMS. On the contrary, we think that FEScycling (coordinated stimulation of lower limbs' muscles to produce the movement of cycling on an ergometer placed on the patients' bed) could be a solution since it involves a great muscle mass during a functional movement [4]. This method has already shown very beneficial effects in populations of patients with no or poor possibilities of lower-limb exercise $[4,5]$, and similar benefits can be expected in patients hospitalized in ICU for COVID-19.

Therefore, although we truly think that the method described by Nakamura et al. [1] might be of great interest, we suggest that the use of FES-cycling would induce greater benefits both at short and long term. Sharing this protocol might allow to establish if FES-cycling has a role to play regarding the burden induced by ICUAW in COVID-19 patients. This represents an important challenge for the patients, healthcare providers, and the societies worldwide.

\section{Acknowledgements \\ Not applicable.}

\section{Authors' contributions}

GD was a major contributor in writing the manuscript. All authors read and approved the final manuscript.

\section{Funding}

None.

Availability of data materials

Not applicable.

Ethical approval and consent to participate

Not applicable.

Consent for publication

Not applicable.

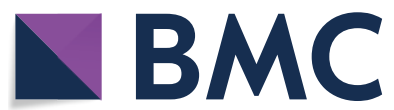

(c) The Author(s) 2021. Open Access This article is licensed under a Creative Commons Attribution 4.0 International License, which permits use, sharing, adaptation, distribution and reproduction in any medium or format, as long as you give appropriate credit to the original author(s) and the source, provide a link to the Creative Commons licence, and indicate if changes were made. The images or other third party material in this article are included in the article's Creative Commons licence, unless indicated otherwise in a credit line to the material. If material is not included in the article's Creative Commons licence and your intended use is not permitted by statutory regulation or exceeds the permitted use, you will need to obtain permission directly from the copyright holder. To view a copy of this licence, visit http://creativecommons.org/licenses/by/4.0/. The Creative Commons Public Domain Dedication waiver (http://creativeco mmons.org/publicdomain/zero/1.0/) applies to the data made available in this article, unless otherwise stated in a credit line to the data. 


\section{Competing interests}

The authors declare that they have no competing interests.

\section{Author details}

${ }^{1}$ INSERM UMR1093 - CAPS, Faculty of Sport Sciences, University of Bourgogne Franche-Comté, 21000 Dijon, France. ${ }^{2}$ Department of Intensive Care, FrançoisMitterrand University Hospital, 21000 Dijon, France.

Received: 23 February 2021 Accepted: 2 March 2021

Published online: 08 March 2021

\section{References}

1. Nakamura $\mathrm{K}, \mathrm{Nakano} \mathrm{H}$, Naraba H, et al. Early rehabilitation with dedicated use of belt-type electrical muscle stimulation for severe COVID-19 patients. Crit Care. 2020;24:342.
2. Pincherle $A$, Jöhrn J, Pancini $L$, et al. Intensive care admission and early neuro-rehabilitation. Lessons for COVID-19? Front Neurol. 2020; 11: 880

3. Thomas P, Baldwin C, Bissett B, et al. Physiotherapy management for COVID-19 in the acute hospital setting: clinical practice recommendations. J Physiother. 2020;66:73-82.

4. Medrinal C, Combret Y, Prieur G, et al. Comparison of exercise intensity during four early rehabilitation techniques in sedated and ventilated patients in ICU: a randomised cross-over trial. Crit Care. 2018;22:110.

5. Deley G, Denuziller J, Babault N. Functional electrical stimulation: cardiorespiratory adaptations and applications for training in paraplegia. Sports Med. 2015:45:71-82.

\section{Publisher's Note}

Springer Nature remains neutral with regard to jurisdictional claims in published maps and institutional affiliations.
Ready to submit your research? Choose BMC and benefit from:

- fast, convenient online submission

- thorough peer review by experienced researchers in your field

- rapid publication on acceptance

- support for research data, including large and complex data types

- gold Open Access which fosters wider collaboration and increased citations

- maximum visibility for your research: over 100M website views per year

At BMC, research is always in progress.

Learn more biomedcentral.com/submissions 